Eur Neurol 2008;59:336-337

DOI: $10.1159 / 000121429$

\section{Straw Peter Syndrome - A Literary Mistake?}

Ozgur Bilgin, Jan Rémi, Soheyl Noachtar

University of Munich, Klinikum Grosshadern Epilepsy Center, Munich, Germany

Dear Sir,

With interest we read the article 'Neurological eponyms derived from literature and visual art' by Dr. Budrys, which was published in European Neurology in 2005 [1]. We would like to comment on a few points of the Straw Peter Syndrome, which is based on the book by Heinrich Hoffmann.

Dr. Heinrich Hoffmann was born in Frankfurt/Main on June 13,1809 . He studied medicine and had a passion for literature. In 1844 he wrote the children's book Struwwelpeter (Straw Peter) as a Christmas gift to his then 3-year-old son.

Dr. Hoffmann was a psychiatrist but erroneously is often referred to as a pediatrician. As a psychiatrist he published on psychiatric issues [2]. In 1851 he founded the first mental hospital (lunatic asylum) in Frankfurt. He considered psychiatric disorders to be medical disorders and rejected the notion of psychiatric patients being criminal or obsessed [3]. He also tried to alter public opinion on mentally ill persons. He died in Frankfurt on September 20, 1894.

Dr. Hoffmann designed the book Straw Peter for his son without any intention to publish it. The book includes 10 separate stories on 10 children who displayed typical undesirable children's behaviors [4]. Straw Peter was the one with long, uncombed hair and long fingernails who refused common hygiene (fig. 1a).
The character who best represents hyperactivity in the book is Fidgety Philip (Zappel-Philipp) (fig. 1b) [5]. He was not able to sit quietly at the table at family dinner (fig. 1b). He kept rocking his chair despite his parents' repeated admonitions. These behavioral characteristics are consistent with many of the ICD-10 criteria for attention deficit hyperactivity disorder (ADHD) [3, 5]. There is another story which also includes aspects of ADHD. Cruel Frederick (Böser Friederich) shows antisocial aggressive behavior which may also be considered at least partly a symptom of ADHD [4].

The story of Johnny-Look-in-the-Air (Hanns-Guck-in-dieLuft) describes a boy who always looked up in the sky and did not hear people warning him. He eventually fell in a hole in the road and into the water [4]. The German epileptologist Dieter Janz felt that Johnny-Look-in-the-Air represents a boy with absence epilepsy but others believed that he more likely was a day-dreaming child $[6,7]$.

All 10 different stories of the book Straw Peter (Struwwelpeter) have a moral to children which has sometimes been regarded as black pedagogy (Schwarze Pädagogik) because of some frightening characters and scary punishments [4].

\section{Discussion}

The stories in Dr. Hoffmann's book reflect universal problems in children's behaviors as well as the universal reactions of parents to these behaviors. For this reason it was translated into more than 30 languages. The English translation was done by Mark Twain. Sigmund Freud [8] appreciated Hoffmann's 'understanding of sexual and other complexes in children'.

Considering all stories, it would be more appropriate to name ADHD after Fidgety Philip rather than using the name of the book Struwwelpeter (Straw Peter), which includes a lot of different problems of child development and misbehavior $[3,5]$. The trans-

Fig. 1. Original illustration of Struwwelpeter (Scrubby Peter) (a) and Zappel-Philipp (Fidgety Philip) (b) by H. Hoffmann.

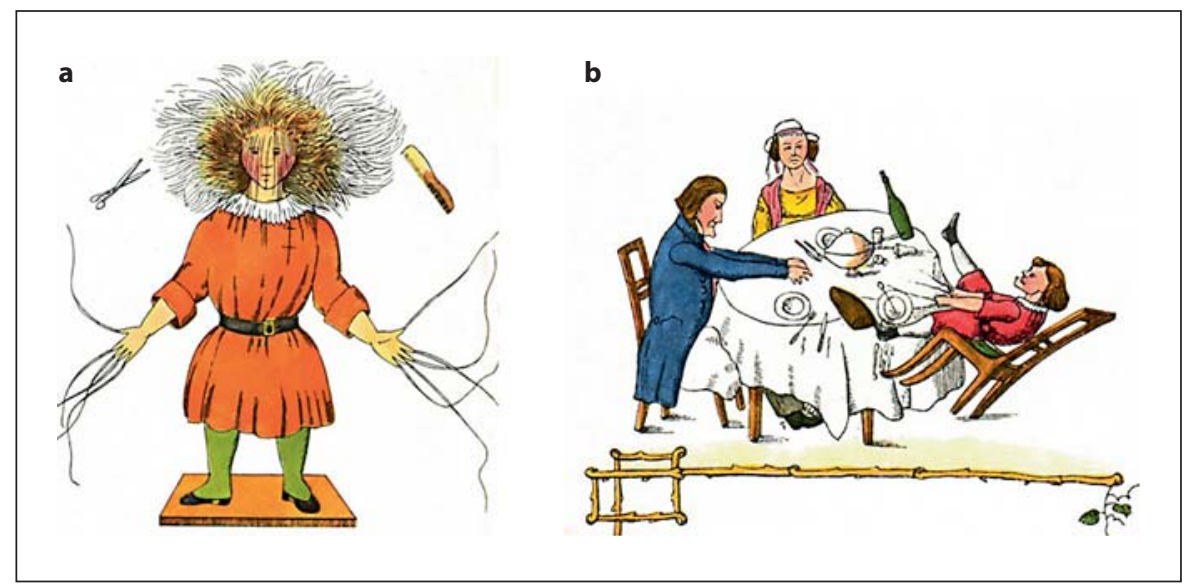

\section{KARGER}

Fax +41613061234 E-Mail karger@karger.ch www.karger.com (c) 2008 S. Karger AG, Base

0014-3022/08/0596-0336\$24.50/0 
lation of 'Struwwelpeter' as 'Straw Peter' is somewhat inaccurate. The English translation of 'Struwwelpeter' by Mark Twain as 'Slovenly Peter' emphasizes the child's character, whereas the German colloquial word 'Struwwel' is a descriptive term of long uncombed hair. The closest English term would be scrubby.

The examples of literary named diseases usually refer to the character who suffers them. Sir Aguecheek in Shakespeare's Twelfth Night is an example. Aguecheek disease (chronic portalsystemic encephalopathy) is named after this character [9].

In conclusion, we think that naming ADHD as Straw Peter Syndrome is misleading and propose to name it after the character of Fidgety Philip (Zappel-Philipp), who displays most of the characteristics of the ADHD syndrome.

\section{References}

1 Budrys V: Neurological eponyms derived from literature and visual art. Eur Neurol 2005;53:171-178

2 Hoffmann H: Beobachtungen und Erfahrungen über Seelenstörungen und Epilepsie in der Irrenanstalt zu Frankfurt am Main (1851-1858); in Hoffmann H, Siefert H (eds): Schriften zur Psychiatre. Frankfurt, Insel, 1859, pp 140-324.

3 Thome J, Jacobs KA: Attention deficit hyperactivity disorder (ADHD) in a 19th century children's book. Eur Psychiatry 2004;19:303-306.

4 Hoffmann H: Der Struwwelpeter. Leipzig, Edition Peters, 1979.

5 Dobson R: Could Fidgety Philipp be proof that ADHD is not a modern phenomenon? BMJ 2004;329:643.

6 Janz D: Die Epilepsien, spezielle Pathologie und Therapie. Stuttgart, Thieme, 1969.

7 Rinnert S, Bauer J: Am Beispiel einer Bildergeschichte. Eine Analyse von Heinrich Hoffmanns Geschichte Hanns-Guck-in-die-Luft aus epileptologischer Sicht. Z Epileptol 2003;16:157-171.

8 Freud S: Studienausgabe. Vorlesungen zur Einführung in die Psychoanalyse und Neue Folge. Frankfurt/Main, Fischer, 1989, vol 1.

9 Summerskill WHJ: Aguecheek's disease. Gut 1978;19:468-469.

Ozgur Bilgin

University of Munich, Department of Neurology

DE-81337 Munich (Germany)

Tel. +49 897095 3691, Fax +49 8970956691

E-Mail ozgurbilgin1@yahoo.com
Eur Neurol 2008;59:337

DOI: 10.1159/000121430

\section{Reply to the Letter by Bilgin et al.: Straw Peter Syndrome - A Literary Mistake?}

Valmantas Budrys

Clinics of Neurology and Neurosurgery,

Vilnius University Faculty of Medicine, Vilnius, Lithuania

Firstly please let me express thanks for the interest in my paper and the valuable comments on Straw Peter Syndrome. I fully agree that Fidgety Philip represents most of the typical attention deficit hyperactivity disorder features; nevertheless other characters of the book also display some of them and together form a complete picture of the syndrome. Concerning renaming of the syndrome, the name of the book Struwwelpeter seems merely more memorable and euphonious, so more suitable for a literary eponym. An analogous example could be the well-known Pickwick syndrome named after the book, not the name of the fat boy Joe. Though somewhat inaccurate, the Straw Peter Syndrome is already anchored in medicine and a difficult task will be to change it.

Valmantas Budrys, MD, PhD

Center of Neurology

Vilnius University Santariskiu Klinikos Hospital

Santariskiu 2

LT-08661 Vilnius (Lithuania)

Tel./Fax +370 52365 220, E-Mail valma@takas.lt 